ppi $201502 Z U 4645$

Esta publicación científica en formato digital es continuidad de la revista impresa ISSN-Versión Impresa 0798-1406 / ISSN-Versión on line 2542-3185Depósito legal pp $197402 Z$ U34

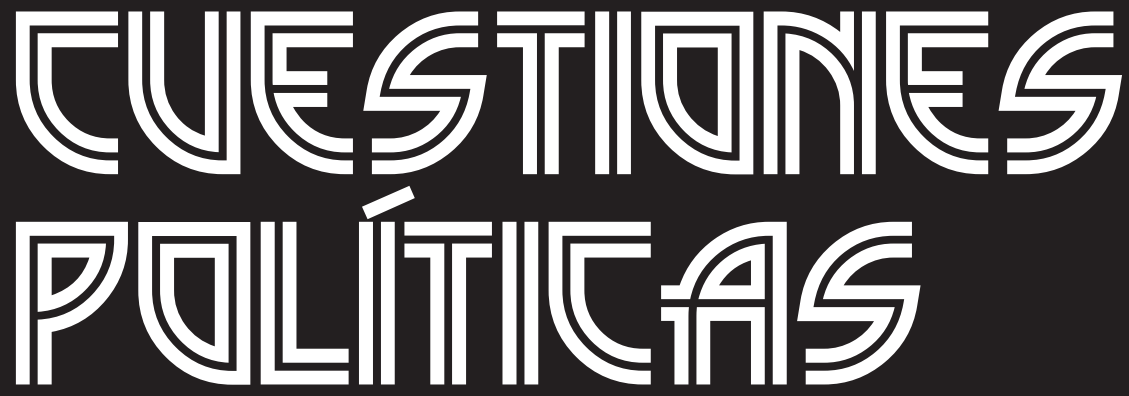

Instituto de Estudios Políticos y Derecho Público "Dr. Humberto J. La Roche" de la Facultad de Ciencias Jurídicas y Políticas de la Universidad del Zulia Maracaibo, Venezuela
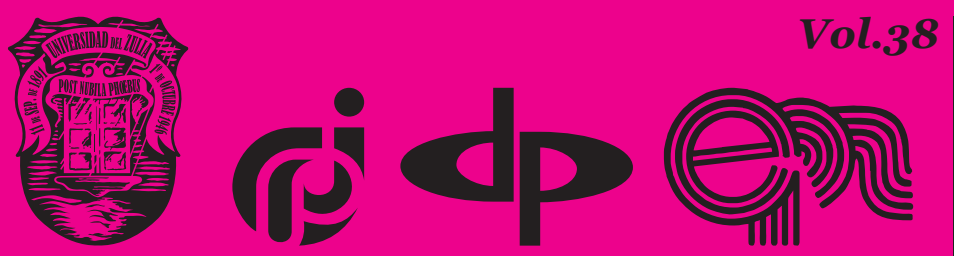

$N^{\circ}$ Especial 1era Parte 2020 


\title{
Student - Volunteer: Aspect of Self- Realization Value in the Context of the Covid-19 Pandemic
}

\author{
DOI: https://doi.org/10.46398/cuestpol.38e.11
}

\author{
Olga G. Tavstukha * \\ Rosalina V. Shagieva ** \\ Artur M. Allagulov *** \\ Yakub A. Ayakoz **** \\ Rashad A. Kurbanov ***** \\ Asiya M. Belyalova \\ Larisa I. Tararina $* * * * * *$
}

\section{Abstract}

In the context of the COVID-19 pandemic, the issues of social capital and mutual aid networks become particularly relevant for the student volunteer in Russia, who independently and, at their own discretion, provides assistance, support and mutual aid. To people in need, as a vital incentive for self-realization. This research aimed to identify the motivating aspects of the need for self-realization of a student volunteer in practical activities to overcome COVID-19. The study method was the test, which allows to identify the characteristics of the content of the value aspects of the self-realization of the volunteer student, determined by the global context of crisis. By way of conclusion, the characteristics of the coronavirus pandemic are revealed as an extraordinary condition for the activity of a student volunteer. Based

* Doctor of Education, Professor of the Department of Preschool, Correctional, Additional Education and Problems of Education, Orenburg State Pedagogical University, Orenburg, Russia. ORCID ID: https:// orcid.org/oooo-0003-1672-3871. Email: olgritav@yandex.ru

** Doctor of Law, Professor of the Department of Private Law, State University of Management, Moscow, Russia. ORCID ID: https://orcid.org/oooo-0003-2239-8892. Email: shagsas@mail.ru

*** Doctor of Education, Professor of the Department of Pedagogy and Sociology, Orenburg State Pedagogical University, Orenburg, Russia. ORCID ID: https://orcid.org/oooo-0001-5490-6818. Email: art_hist@bk.ru

****Post-Graduate Student of the Department of General and Professional Pedagogy, Orenburg State University, Orenburg, Russia. ORCID ID: https://orcid.org/oooo-0002-1914-4501. Email: ayagoz2408@mail.ru

*****Doctor of Law, Professor, Head of the Department of Civil Law Disciplines, Plekhanov Russian University of Economics, Moscow, Russia. ORCID ID: https://orcid.org/oooo-0001-7900-1302. Email: mos-ssp@mail.ru

***** PhD in Law, Head of the International Cooperation Department, Institute of Legislation and Comparative Law under the Government of the Russian Federation, Moscow, Russia. ORCID ID: https://orcid.org/oooo-ooo2-8916-4559. Email: asyulya@mail.ru

****** $\mathrm{PhD}$ in Education, Associate Professor of the Department of Linguistics and Translation, Russian State Social University, Moscow, Russia. ORCID ID: https://orcid.org/oooo-0002-2562-5344. Email: lt31@mail.ru

Recibido: 02/03/2020

Aceptado: 06/04/2020. 
on the results of the study, a self-realization value model of a volunteer student is confirmed in the extraordinary conditions of the coronavirus pandemic. The practical importance of the model is demonstrated with the help of cognitive criteria typical of activity-based social psychology for the formation of value aspects of the self-realization of a volunteer student.

Keywords: Pandemia de COVID-19; voluntariado en Rusia; valores humanitarios del voluntariado; autorrealización de estudiante-voluntario; pruebas psicológicas y pedagógicas.

\section{Estudiante - Voluntario: aspectos del valor autorrealización en el contexto de la pandemia de Covid-19}

\section{Resumen}

En el contexto de la pandemia de COVID-19, los temas de capital social y redes de ayuda mutua se vuelven particularmente relevantes para el estudiante voluntario en Rusia, quien de manera independiente y, a su propia discreción, brinda asistencia, apoyo y ayuda mutua a las personas necesitadas, como un incentivo vital para la autorrealización. Esta investigación tuvo como objetivo identificar los aspectos motivadores de la necesidad de autorrealización de un estudiante voluntario en actividades prácticas para superar el COVID-19. El método del estudio fue la prueba, que permite identificar las características del contenido de los aspectos de valor de la autorrealización del estudiante voluntario, determinado por el contexto global de crisis. A modo de conclusión se revelan las características de la pandemia de coronavirus como una condición extraordinaria para la actividad de un estudiante voluntario. Con base en los resultados del estudio, se confirma un modelo de valor de la autorrealización de un estudiante voluntario en las condiciones extraordinarias de la pandemia de coronavirus. La importancia práctica del modelo se demuestra con la ayuda de criterios cognitivos propios de la psicología social basada en actividades para la formación de aspectos de valor de la autorrealización de un estudiante voluntario.

Palabras clave: Pandemia de COVID-19; voluntariado en Rusia; valores humanitarios del voluntariado; autorrealización de estudiante-voluntario; pruebas psicológicas y pedagógicas. 
Olga G. Tavstukha, Rosalina V. Shagieva, Artur M. Allagulov, Yakub A. Ayakoz, Rashad A. Kurbanov, Asiya M. Belyalova y Larisa I. Tararina

\section{Introduction: Research Relevance}

The beginning of the XXI century of our civilization is characterized by global contradictions. On the one hand, these are achievements in scientific fields, in the field of digital technologies, in robotics, and on the other- there is an increasing of risks caused by extreme natural and climate disasters, emergencies, and the intensification of man - made environmental disasters. As a rule, human casualties, global losses in the national economies of countries and regions, and irreparable damage to the human and animal habitat accompany dangerous risks (Bystrova et al, 2018; Colin, 2014). At the world Economic Forum (Global Risks Report, 2019), forum experts specialists of various profiles and levels, heads of States and corporations prepared and presented a report on global risks.

Assessing the results of the past year and identifying the main problems of the coming year, they set a key strategy for sustainable development of our time: "environmental problems are the leading issues. They will maintain their dominance in the future" (Global Risks Report, 2019). Based on the analysis of the main global threats to humanity and trends that may affect the degree of influence or change in their specific weight, the forum participants formulated objective prerequisites for global risks, grouped according to the traditional classification established in the world practice: geopolitical, environmental, economic, social and technological (Colin, 2014).

The coronavirus pandemic of 2020 crossed out all the conclusions of the forum participants: it destroyed the existing stereotypes of environmental reality, revealed the incorrectness of the traditional classification of global risks, the authors of which did not take into account the dominance of viral risks in the surrounding space. Emphasizing the extreme danger of viral risks for the sustainable development of human civilization, Russian President Vladimir Putin in his Address to the citizens of Russia noted the importance of a person, his/her active life position, responsibility, and selfactualization:

At all times, representatives of different classes, ages, views have selflessly served the Fatherland, people, actively participated in education and charity, contributed to solving socially significant problems in the fields of education, health, culture, and ecology. Today, representatives of modern students who are not indifferent to the problems of society are actively helping to overcome a new, terrible scourge - the coronavirus pandemic (Putin, 2020:48).

In the context of the COVID-19 pandemic, a special role is assigned to student volunteers, along with government, public, faith-based structures, representatives of non-profit, commercial organizations and individuals of private property, who fulfill this activity independently and at their own 
discretion, as the highest personal need and a vital motive, providing support and assistance to people who find themselves in a dangerous situation of coronavirus infection.

In the absence of radical means to overcome the COVID-19 pandemic, student volunteers provide assistance to those in need with all available means and resources based on the humanitarian values of mercy and compassion in the name of saving human health and life. Due to the current circumstances, the research as an independent scientific direction is the first attempt to determine the theoretical and methodological aspects of self - actualization of a modern student - volunteer, aimed at helping people who are in a dangerous situation of the COVID-19 pandemic.

The article reveals the features of the coronavirus pandemic as an extraordinary condition for self - actualization of a student-volunteer; defines the need-motivational functions of self - actualization of a studentvolunteer in the practice of overcoming COVID-19. Based on the results of the study, it substantiates a value model of self - actualization of a student volunteer in the extraordinary conditions of a coronavirus pandemic. The practical significance of the model is proved with the help of value-semantic, motivational-need and functional - regulatory criteria for the formation of value aspects of self - actualization of a student-volunteer.

\section{Literature Review}

The theoretical basis of this research is the conceptual approaches of A. Maslow (2011), the founder of the humanistic direction in personality psychology. Defining the characteristics of self-actualizing people based on his own empirical research, A. Maslow identified the most dominant among them: self-acceptance, acceptance of other people and (surrounding) nature, focus on solving primary problems, independence from cultural clichés and environment, and the democratic nature of relations.

The characteristics of a self-actualized personality, identical to the approaches of (Maslow, 2011) are presented in the research of other psychologists. In the works of K. Rogers (1990) and H. Heckhausen (2003), self - actualized people are people who are open to new experiences, external and internal stimuli, experiencing both positive and negative emotions; living existentially, constantly in the process of change, having flexibility and the ability to adapt; having an internal locus of control; showing creativity in any kind of activity, realizing the significance of their potential.

In the modern psychological and pedagogical literature devoted to the problems of self - actualization of the student-volunteer personality, 
Olga G. Tavstukha, Rosalina V. Shagieva, Artur M. Allagulov, Yakub A. Ayakoz, Rashad A. Kurbanov, Asiya M. Belyalova y Larisa I. Tararina

various approaches are traced. In the works of E.E. Vakhromov (2001), S.G. Ekimov (2010), V.I. Markelov (2011), M.V. Pevnaya (2016), self - actualization is considered as a set of values that stimulate the selfdevelopment of a student-volunteer, giving him/her the highest qualities of personal needs, goals and life strategies of the individual. In the collective work of N.V. Bystrova, S.A. Tsyplakova and L.A. Chumakova (2018), in the dissertation research of E.V. Samal (2008), self-actualization is identified with the process of personal development as a subject of volunteer activity. In the study of O.A. Idobayeva and G.I. Reznitskaya (2008), in the textbook by O.V. Reshetnikov (2005), self-actualization appears as a condition of psychological well-being of the individual.

In the works of V.I. Markelov (2011), M.V. Pevnaya (2016), K. Rogers (1990), self - actualization is considered as an indicator of personal maturity of a student-volunteer. In all works, special importance is attached to the key idea of self - actualization of the student-volunteer-orientation to the implementation of the values of mutual assistance, charity, compassion, justice, tolerance, the ability to bear independent responsibility for the assigned work, readiness to protect the subject as the highest personal need and goal of life.

\section{Results}

\subsection{Features of the COVID-19 Coronavirus Pandemic - an Extraordinary Condition for Self - Actualization of a Student Volunteer}

The coronavirus pandemic of 2020 is an extraordinary phenomenon that has no analogues in the history of humanity. It has the character of a global pandemic, from which now there is no effective means of protection. The pandemic instantly changed all the well-established plans, perspectives, behaviors, and forms of activity in people's lives. The dangers of COVID-19 risks, in the figurative words of the Executive Director of the world Health Organization, represent a threat of unprecedented scale, surpassing world wars in the number and speed of destruction of people (Ryan, 2020). The everyday, familiar life of people turned into an ongoing struggle with an invisible, cruel enemy. Before the risk of infection, most countries spontaneously close interstate borders, stop tourist exchanges, all communications are transferred to online mode, cultural and sports events that have the status of world Championships are canceled or postponed indefinitely. 
Even NATO military exercises in Europe have been canceled. There are previously unusual forms of behavior of people: a ban on handshakes, hugs, keeping a distance of 1.5-2 meters between people, the daily use of medical masks and gloves in transport, in stores, when visiting any places where people gather, the systematic use of antiseptics to avoid the spread of infection. The main principle of countering the spread of infection is the self-isolation of elderly people in the age category +60 and people with chronic diseases and weakened health.

All other age categories are subject to quarantine. In Russia, students of secondary schools and all other institutions, University students, employees of small, medium and major industries and institutions, with the exception of those companies that provide the population with vital food, medicine, household sanitation are sent to be quarantined and their activity is organized by "remote" principle. The slogans Stay at home! and Be at home! - have become familiar in everyday life of people, as a reminder of the deadly danger. Millions of elderly and frail people have become selfisolated and have become in dire need of daily help from volunteers.

In this regard, the volunteer activity of the student-volunteer is being re-profiled. It is becoming more specialized and pragmatic, mainly aimed at helping the elderly in the age category +60 , people with chronic diseases, as well as those affected or at risk from COVID-19. A new classification of student - volunteer activities focused on helping people in self-isolation and quarantine has been defined:

1) Assistance to elderly people of the age category +60 and persons with impaired health:

- Delivery of food, medicine, and necessities.

- assistance in pet care.

- Payment for utilities, cleaning of residential premises, garbage removal. walking Pets and other urgent types of household chores.

2) Assistance to disabled people (without age category). Activities are similar to the category Elderly people.

3) Donation for COVID-19 patients.

4) Assistance in providing food and veterinary supplies to animals in zoos, local and nonresident circuses that arrived on tour and did not have time to go home before the introduction of quarantine.

5) Assistance to social services in carrying out preventive measures of quarantine compliance (distribution of informational posters, leaflets, logos that explain the danger of infection to the population, demonstrate measures of protection and behavior in the environment). 
Olga G. Tavstukha, Rosalina V. Shagieva, Artur M. Allagulov, Yakub A. Ayakoz, Rashad A. Kurbanov, Asiya M. Belyalova y Larisa I. Tararina

6) Prevention and neutralization of panic rumors.

7) Informing the population about the reasons and necessity of selfisolation of people during the quarantine period.

Psychological and pedagogical testing conducted in the course of the study shows that such intensive and dangerous activities for the health and life of a student - volunteer require special knowledge and individual qualities based on the rapid application of the humanitarian values of selfactualization in the context of a pandemic: focus on compassion, on mercy to people in trouble, on providing mutual assistance in the name of saving people's health and life; independence, flexibility and originality of thinking; courage, curiosity, creativity; activity, perseverance in saving the health and lives of victims. Testing confirms the assumption that self-actualization is used: 1) as a process that has its own characteristics of manifestation in the activities of a student - volunteer during COVID-19; 2) as an integrative personal formation, represented by a clear structure of values focused on overcoming coronavirus infection.

\subsection{Need-Motivational Functions of Self - Actualization of a Student-Volunteer in Practical Activities (COVID-19)}

Self-actualization in the works of modern researchers is considered as a mechanism that stimulates the self-development of the individual and directs his/her needs, motives and life strategies to implement higher requirements for the qualities of independence, initiative, social courage, responsibility (Ekimova, 2010; Samal, 2008; Heckhausen, 2003). However, the picture of the world, which has changed under the influence of COVID-19, reveals the features of this process from a new perspective. In relation to the activity of a student - volunteer, an important aspect is to rethink and expand the need - motivational functions of planning types of volunteer activities to help people who are in self-isolation and quarantine.

This process is determined by the personal position of the student volunteer, as his/her highest need is to independently and at his/her own discretion distribute the humanitarian values of providing assistance to victims of coronavirus. Common sense, knowledge of their business, the ability to comprehend crisis situations, subject them to rapid and clear analysis, strong-willed attitude to overcoming the pandemic, understanding and acceptance of the values of self-actualization in volunteer activities, constancy in the search for means to protect people from coronavirus, allow the student - volunteer to quickly solve the tasks set. Individual forms of interaction with self-isolated people become for the volunteers a prototype 
of activity in which they implement their need - motivational functions of self-actualization. In his work O.V. Reshetnikov (2005) quite correctly and evidently reveals the features of the implementation of the need motivational functions of self-actualization of the volunteer's personality, which are carried out in the process of diagnosing the psychological state of the individual in need, determining the necessary assistance, clarifying the requirements for assistance, organizing and conducting Advisory activities.

Based on the conclusions of O.V. Reshetnikov (2005), an experimental verification of the validity of the need - motivational functions of self actualization of a student-volunteer in the activity of assisting self-isolated and quarantined people was carried out. It is established that in the process of such interaction, favorable conditions are created for establishing a new model of interaction in direct, live contact with a person. The new model of interaction, in addition to the delivery of food and medicine, garbage removal and pet walking, allows us to solve other problems of a social nature that are no less important for the state and self-isolated people:

- reducing the level of social tension in society, which has a positive impact on the psychology of public consciousness.

- increasing the socially responsible self-awareness of citizens.

- increasing the country's authority in international relations.

- Infrastructure expansion.

- improving Internet technologies and online platforms for helping victims.

- Increase in the number of voluntary projects implemented in conjunction with social structures.

- expanding the number of volunteer groups ready to help victims of coronavirus.

- using various Internet technologies to promptly and timely inform the population about the solution of emerging problems.

The correlation of indicators of the student's personal position as a volunteer and the values of volunteer activity in the main directions of the new model of interaction correspond to the criteria of the need-motivational functions of self-actualization in the practical activity of overcoming coronavirus infection:

- Motivational focus on overcoming coronavirus infection.

- needs for assistance to victims.

- Life support for subjects affected by COVID-19.

- Social success in the fight against coronavirus. 
Olga G. Tavstukha, Rosalina V. Shagieva, Artur M. Allagulov, Yakub A. Ayakoz, Rashad A. Kurbanov, Asiya M. Belyalova y Larisa I. Tararina

176 Student - Volunteer: Aspect of Self-Realization Value in the Context of the Covid-19 Pandemic

\subsection{Value Model of Self - Actualization of a Student- Volunteer in the Extraordinary Conditions of a Coronavirus Pandemic}

During psychological and pedagogical testing, the key components of the value model of a student-volunteer's self - actualization in the extraordinary conditions of a coronavirus pandemic were established. The model is based on a set of theoretical ideas and assumptions about the dynamics of values of self-actualization, presented to varying degrees in a number of studies of teachers, psychologists, sociologists (Vakhromov, 2001; Ekimova, 2010; Markelov, 2011; Maslow, 2011; Rogers, 1990; Pevnaya, 2016; Samal, 2008; Heckhausen, 2003).

The first level of the model. Invariant modules of self-actualization values:

1. Orientation in time. It reveals the extent of the student's objective assessments of their time: pride for past events, respect for today's coronavirus control processes, understanding the dangers of COVID-19 risks, hope for better changes, awareness of their place and role in the positive transformations of time.

2. Orientation of the student's personality towards him/herself or people waiting for help. An indicator of self-sufficiency of the individual, the formation of beliefs, principles, and attitudes in working with self-isolated people. It indicates flexibility of thinking, tolerance, or conformity.

3. Value orientations. The most important element of the internal structure of the student - volunteer's personality. Their presence indicates the social maturity of the student, which caused awareness of the choice of working with people who are in a dangerous situation of coronavirus infection. Formation of valuable orientations of student is seen in the activities of the volunteer as integrity, reliability, loyalty to the principles and ideals of charity, mutual assistance, protection of health and life of people, the ability to strong-willed efforts in the name of these ideals and values, active life position, persistence in achieving goals.

Second level. Multivariate modules of student's personality properties and qualities:

1. Active life position of a student-volunteer. This indicates that the principles of charity, mutual assistance, and compassion have been formed in relation to all categories of people affected by COVID-19. In an active life position, the student - volunteer reveals the moral values that determine the nature of behavior, unity of word and deed, and intransigence to all manifestations of evil and injustice. 
2. Cognitive activity of a student-volunteer. The severity of the desire to acquire knowledge about the world, cognitive interest, the formation of receptions of mental activity, readiness level to understanding of the processes of infection, death, his/her role and place in the salvation of their wards. Cognitive activity characterizes the entire life of the student; it influences his/her success in activities, the status of a professional volunteer. Cognitive activity of a student-volunteer is a stable personal formation and personal quality.

3. Communication skills of the student-volunteer. Positive moral and ethical quality of a student-volunteer, which is manifested in communication, establishing contacts, relationships, and connections with people who receive the necessary assistance. In the conditions of communication of a student-volunteer with selfisolated people, this quality is manifested as sociability. Sociability is based on the student's ability to create a benevolent atmosphere around people who are in fear of the inevitability of infection, to establish psychological compatibility with the wards, to position them to themselves through various methods, ways, and actions.

4. Creativity. Creative abilities of a student-volunteer based on the readiness to produce fundamentally new ideas to help their wards and quickly solve problem situations. According to the conclusions of A. Maslow (2011), creativity is a creative orientation that is innately inherent in all but lost by most under the influence of the environment. In the context of a coronavirus pandemic, the creativity of a student volunteer affects the environment and cleanses it from infection, bringing it closer to the previous standards of safe living of humanity.

Third level. Psychological module:

1) Psychological characteristics of a person determined by the values of self - actualization of a student-volunteer in the context of a coronavirus pandemic.

2) meaning-life orientations of the student - volunteer's personality.

3) Personal level of control of behavior in activities with categories of self-isolated people and people in quarantine.

4) Self-assessment of their own activities with victims of COVID-19.

Fourth level. Criteria-based module. It defines the meaning of student volunteer's self-actualization values in practical activities (COVID-19:

1) value-semantic criterion defines and specifies value orientations, individual and social goals, strategies, behavioral models, and the content of the student's activity in helping a person in the extraordinary conditions of a pandemic. 
Olga G. Tavstukha, Rosalina V. Shagieva, Artur M. Allagulov, Yakub A. Ayakoz, Rashad A. Kurbanov, Asiya M. Belyalova y Larisa I. Tararina

178 Student - Volunteer: Aspect of Self-Realization Value in the Context of the Covid-19 Pandemic

2) motivational-need criterion determines the motivational orientation and need of a student-volunteer in the implementation of life support for people affected by coronavirus.

3) Functional and regulatory criteria coordinate the behavior of a student - volunteer in the process of providing mutual assistance to people affected by COVID-19, identifies the reflection, independence, responsibility of the student in the context of a pandemic.

\section{Conclusion}

The research confirms the theoretical and practical significance of an innovative approach to substantiating the value aspects of self-actualization of a modern student-volunteer. This is due to the extraordinary nature of the global coronavirus pandemic, its suddenness, intensity, and apocalyptic destructiveness.

The pandemic takes thousands of lives every day and isolates States, communities, and individuals. Before the fear of deadly danger, people are self-isolated in a closed space, deprived of the usual contacts with relatives and close associates. In the figurative words of WHO Executive Director - M. Ryan, the coronavirus pandemic is a threat of unprecedented scale, surpassing world wars in the number and speed of destruction of people. Emphasizing the extreme danger of viral risks to human civilization, Russian President Vladimir Putin in his Address to the citizens of Russia notes the special role in overcoming COVID-19 of student volunteers, their active life position, responsibility, and self-sacrifice. In the absence of radical means to overcome the COVID-19 pandemic, assistance by student volunteers is provided by all available means and resources based on the humanitarian values of mercy, compassion in the name of saving human health and life.

In connection with the current circumstances caused by the COVID-19 pandemic, the study for the first time, as an independent scientific direction, carried out a theoretical and methodological justification of the value aspects of self - actualization of a modern student - volunteer, aimed at helping people who find themselves in a dangerous situation of coronavirus infection. The article reveals the features of the coronavirus pandemic as an extraordinary condition for self - actualization of a student-volunteer; defines the need-motivational functions of self - actualization of a studentvolunteer in the practice of overcoming COVID-19. Based on the results of the study, the effectiveness of the value model of a student-volunteer's self - actualization in the extraordinary conditions of a coronavirus pandemic is proved. The practical significance of the model is proved using a set of value-semantic, motivational-need and functional-regulatory criteria. 
The process of studying the value aspects of self - actualization of a student-volunteer in the process of overcoming the coronavirus pandemic is not completed by solving the tasks of the study. The study of psychological deformations of people caused by the influence of self-isolation and quarantine in the extraordinary conditions of COVID-19 is also of particular interest to future researchers.

\section{Bibliographic References}

BYSTROVA, Natalia V; TSYPLAKOVA, Svetlana A; CHUMAKOVA, Lyuba A. 2018. Volunteer movement as a factor in the development of social activity of young people. Karelian scientific journal. Pedagogical Sciences. Vol. 1, No. 22, pp. 73-76.

COLIN, Khoury K. 2014. "Global threats to the development of civilization in the XX1 century" In: Strategic priority. No. 1, pp. 6-30.

EKIMOVA, Sergey G. 2010. Volunteer activity as a resource for personal and professional development of future specialists in social work: Abstract of PhD. Khabarovsk (unpublished).

GLOBAL RISKS REPORT. 2019. Report on global risks of 2019 at the world Economic Forum. Davos, Suzie.

HECKHAUSEN, Heinz. 2003. Motivation and activity. Piter. Saint Petersburg, Russian.

IDOBAYEVA, Olga A. \& REZNITSKAYA, Grigory I. 2008. "Self-actualization of personality as a condition of psychological well-being of a modern student" In: Bulletin of the Moscow city pedagogical University. Vol. 16 No. 622, pp. 29-41.

MARKELOV, Vladimir I. 2011. About the levels of self-actualization and the need for their allocation. website of the international scientific analytical project. Available online. In: http://www.gisap.eu/ru/node/1397. Date of consultation: 06/02/2020.

MASLOW, Abraham Harold. 2011. New frontiers of human nature. Smysl. Moscow, Russian.

PEVNAYA, MariaV.2016. Volunteer management: international experienceand local practices. Publishing house of the Ural University. Yekaterinburg, Russian. 
Olga G. Tavstukha, Rosalina V. Shagieva, Artur M. Allagulov, Yakub A. Ayakoz, Rashad A. Kurbanov, Asiya M. Belyalova y Larisa I. Tararina

180

Student - Volunteer: Aspect of Self-Realization Value in the Context of the Covid-19 Pandemic

PUTIN, Vladimir V. 2020. Appeal to the citizens of Russia. Available online. In: http://kremlin.ru/events/president/news/copy/63133. Date of consultation: 13/02/2020.

RESHETNIKOV, Oleg V. 2005. Organization of volunteer activities. Educational and methodological guide. Foundation for assistance to education of the XXI century. Moscow, Russian.

ROGERS, Kem. 1990. "Several important discoveries. Bulletin of MSU. Ser" In: Psychology. No. 2, pp. 58-65.

RYAN, Michael G. 2020. Address to the participants of the COVID-19 flash briefing. Available online. In: https://www.who.int/ru/news-room/ detail/13-02-2020-remarks-by-dr-michael-ryan-executive-directorwho-health-emergencies-programme-at-media-briefing-on-covid-19on-13-february-2020. Date of consultation: 13/02/2020.

SAMAL, Elena.V. 2008. Self-actualization of the individual in the process of studying at the University: PhD Thesis. Yaroslavl. (unpublished).

VAKHROMOV, Evgenij E. 2001. Psychological concept of human development: theory of self-actualization. International pedagogical Academy. Moscow, Russian. 


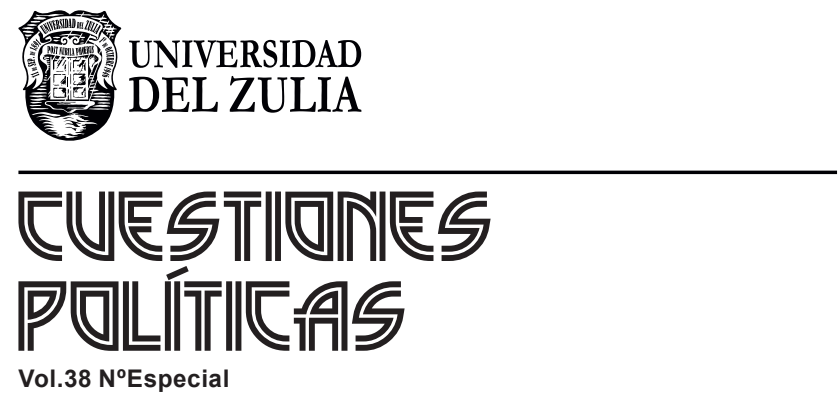

www.luz.edu.ve 